\title{
KOORDINASI DAN JARINGAN PENELITIAN : Studi pada IAIN Raden Intan Bandar Lampung
}

\section{Oleh : Harisun Arsyad}

\section{PENDAHULUAN}

Tulisan ini merupakan bagian dari studi pengembangan jaringan penelitian di lingkungan Departemn Agama. Sebagaimana diketahui bahwa tugas Badan Litbang Agama adalah menyelenggarakan pembinaan semua unit penelitian dan pengembangan di Lingkungan Departemen Agama, baik yang diselenggarakan sendiri oleh Badan Litbang Agama maupun yang diselenggarakan oleh unsur-unsur lain di lingkungan Departemen Agama. Namun yang menjadi permasalahan Badan Litbang Agama saat ini adalah pelaksanaan koordinasi dengan unit lain di lingkungan Departemen Agama seperti lembaga penelitian IAIN belum berlangsung secara efektif; sehingga sering kita dengar terjadi duplikasi dan replikasi di dalam pelaksanaan penelitian. Untuk meningkatkan koordinasi serta menghindari terjadinya duplikasi kegiatan, maka pada tahun anggaran 1995/1996 Badan Litbang Agama melakukan Studi Pengembangan Jaringan Penelitian Keagamaan, dengan sasaran utama adalah lembaga penelitian di lingkungan IAIN.

Studi ini bertujuan meningkatkan kerjasama secara terpadu antara Badan Litbang Agama dengan unit-unit pelaksana penelitian di Lingkungan Departemn Agama, guna menyusun kebijaksanaan program penelitian dan pemanfatan/persebaran hasil-hasilnya. Juga melalui kegiatan ini diharapkan akan menghasilkan sebuah kerjasama bagi pengembangan sebuah jaringan penelitian keagamaan di Lingkungan Departemen Agama.

Penelitian dilaksanakan di Kampus IAIN Raden Intan Bandar Lampung, men- cakup kampus lama yang berlokasi di jalan Teuku Umar Labuhan Ratu Bandar Lampung dan kampus baru yang berlokasi di Sukarame.

Dalam kesempatan penelitian ini digunakan pendekatan kualitatif dengan teknik pengumpulan data melalui pengamatan, wawancara bebas terkendali dan studi dokumen/perpustakaan.

\section{Sejarah Singkat dan Potensi IAIN Raden Intan}

IAIN Raden Intan berdiri pada tanggal 26 Oktober 1968 berdasarkan SK Menteri Agama Nomor 187 Tahun 1968 dengan nama lengkap Institut Agama Islam Negeri Al-Jami'ah Al-Islamiyah AlHukumiyah Raden Intan Lampung. Sebagai lembaga pendidikan, IAIN Raden Intan lahir dan berkembang dari sebuah Yayasan Perguruan Tinggi Islam (YAPERTI) Lampung yang dibentuk oleh Yayasan Kesejahteraan Lampung (YKIL) pada tahun 1966. YKIL adalah sebuah yayasan sosial yang didirikan pada tahun 1961 di Lampung dan berkedudukan di Tanjung Karang dengan tujuan untuk menyelenggarakan pendidikan Islam dan membangun tempat-tempat ibadah.

Sejak bedirinya hingga kini IAIN Raden Intan telah banyak melakukan aktivitas sesuai dengan Tri Dharma Perguruan Tinggi malalui bidang pendidikan, penelitian, pengabdian kepada masyarakat dan bidang-bidang kegiatan lainnya. Hal ini sejalan dengan dicabutnya PP Nomor 33 Tahun 1985 dengan PP No. 13 Tahun 1991 dan Keppres No. 9 Tahun 1987 dengan Keppres Nomor 10 Tahun 1991 yang menjadikan kedudukan sejajar 
dengan perguruan tinggi umum sebagaimana diatur oleh Undang-undang Nomor 2 Tahun 1989 tentang Sistem Pendidikan Nasional dan PP Nomor 30 Tahun 1990 tentang Pendidikan Tinggi.

Di bidang pendidikan dan pengajaran IAIN Raden Intan memiliki 5 buah fakultas yang terdiri atas : (1) Fakultas Tarbiyah Bandar Lampung, (2) Fakultas Tarbiyah Metro, (3) Fakultas Ushuluddin, (4) Fakultas Syari'ah, (5) Fakultas Dakwah dan satu program D.2 Tarbiyah. Menurut Statuta IAIN Raden Intan yang dituang dalam Keputusan Menteri Agama Nomor 411 Tahun 1993 penyelenggaraan pendidikan dan pengajaran tersebut didukung oleh 1 (satu) Biro yang membawahi 5 (lima) Kepala Bagian ; 3 (tiga) Pusat : Pusat Penelitian, Pusat Pengabdian Kepada Masyarakat dan Pusat Komputer; serta Perpustakaan. Pada tiaptiap fakultas terdapat 1 (satu) Bagian Tata Usaha yang membawahi 3 (tiga) Sub Bagian; Jurusan dan Laboratorium/Studio serta Kelompok Tenaga Pengajar. Dalam memasuki usia yang ke 27 perkembangan IAIN Raden Intan terlihat semakin meningkat dan dinamis. Kenyataan ini tergambar dari perkembangan sumber day a yang dimiliki, seperti dosen, tenaga administrasi dan mahasiswa. Pada tahun akademik 1995/1996 tercatat sekitar 132 orang tenaga pengajar/dosen, 202 orang tenaga administasi, 74 orang honorer dan 5.240 mahasiswa.

Dilihat dari segi perkembangan dosen selma 4 tahun terakhir (1990-1994) terdapat kenaikan sebanyak 24 orang $(22,22 \%)$. Para dosen tersebut menyebar hampir merata ke semua fakultas kecuali untuk Fakultas Dakwah yang sama sekali belum memiliki dosen tetap sehingga diperlukan tambahan. Latar belakang pendidikan mereka masih didominasi oleh lulusan Strata I dengan perincian SI sebanyak 118 orang $(89,39 \%)$ dan S2 sebanyak 14 orang $(10,61 \%)$.

Di masa mendatang kondisi pendidikan dosen agaknya akan semakin bertambah baik dengan dilakukan peningkatan mutu dosen secara kontinyu, diantaranya pada saat ini terdapat sejumlah dosen yang sedang mengikuti program S2 dan S3 di dalam maupun luar negeri, masing-masing jenjang berjumlah sembilan orang. Dan berdasarkan kenyataan yang ada dewasa ini ratio dosen dengan mahsisiwa adalah 1 dosen berbanding 28 orang mahasiswa. Ratio ini tampak masih belum memadai karena yang diharapkan adalah 1 dosen berbanding 15 mahasisiwa.

Di pihak lain penyebaran tenaga administrasi pada umunya telah menjangkau seluruh unit di lingkungan IAIN Raden Intan sesuai dengan beban kerja dari masing-masing unit. Perkembangan tenaga administrasi selama 4 tahun juga mengalami kenaikan sebanayak 13 orang $(6,88 \%)$.

Minat masyarakat Lampung untuk melanjutkan studi ke IAIN Raden Intan cukup banyak, dengan basis pendidikan yang cukup bervariasi yaitu : PGA, Madrasah Aliyah (MA), SMA dan SMEA. Memperhatikan basis asal mahasiswa yang bervariasi ini cukup menarik, karena ternyata mereka yang berminat masuk ke IAIN tidak saja berasal dari sekolah-sekolah yang bercirikan agama tetapi juga dari sekolah umum. Kendati demikian mereka yang tidak diterima di perguruan tinggi ini juga cukup banyak. Diduga karena latar belakang pengetahuan agama mereka tergolong rendah menyebabkan sebagian mereka tidak bisa diterima. Hal ini bisa dilihat dari perbandingan antara jumlah pendaftar dengan yang diterima, seperti pada tabel berikut. 
KOORDINAS1 DAN JARINGAN PENELITIAN

Studi pada IAIN Raden Intan Bandar Lampung

\section{Tabel Jumlah Calon Mahasiswa \\ Yang mendaftar dan diterima di IAIN \\ Raden Intan Tahun Akademik 1992-199\$}

\begin{tabular}{|c|c|c|c|c|}
\hline \multirow{2}{*}{ NO, } & \multirow{2}{*}{ TAHUN JKADEMIK } & \multicolumn{2}{|c|}{ J U M L A H } & \multirow{2}{*}{$\begin{array}{c}\text { SELISI } \\
(*)\end{array}$} \\
\hline & & CALON & YG DITERIMA & \\
\hline 1. & 1992-1993 & 785 & 602 & $\begin{array}{c}183 \\
(23,31)\end{array}$ \\
\hline 2. & 1993-1994 & 752 & 614 & $\begin{array}{c}138 \\
(18,35)\end{array}$ \\
\hline 3. & 1994-1995 & 863 & 722 & $\begin{array}{c}141 \\
(16,34)\end{array}$ \\
\hline
\end{tabular}

Pada tahun akademik 1994-1995 penyebaran mahasiswa menurut fakultas dapat dirinci sebagai berikut: Fak. Tarbiyah Bandar lampung 186 orang, Fak. Syari'ah 133 orang, Fak. Ushuluddin 132 orang, Fak. Tarbiyah metro 114 orang, Fak. Dakwah 117 orang dan Program D2 Tarbiyah 40 orang.

Untuk mengimbangi membludaknya mahasiswa pimpinan IAIN juga tidak henti-hentinya nelakukan upaya peningkatan kualitas sumber daya manusia. Untuk peningkatan mutu dosen dilakukan langkah-langkah sebagai berikut:

a. Mengikutsertakan dalam program S2 dan S3 di dalam maupun di luar negeri dengan bantuan dana pendidikan.

b. Mengikutsertakan dalam diklat penelitian, pembibitan dosen dan jaringan penelitian di pusat maupun daerah.

c. Mengadakan atau mengikutsertakan pada seminar, diskusi lokal maupun regional.

d. Menggiatkan semangat menulis karya tulis.
Sedangkan peningkatan kualitas di kalangan tenaga administrasi dan pustakawan ditempuh melalui kegiatan diklat pustakawan yang diselenggarakan oleh Departemen Agama maupun Perpustakaan Nasional dan Daerah, Pra Jabatan, Sepala, Bendaharawan, P-4 dan kursus komputer. Untuk kalangan mahasistwa upaya penigkatan dan pengembangan mutu sumber daya marlusia dilakukan melalui penyaringan ujian masuk, penerapan kurikulum 1994, peningkatan laboratorium dan perpustakaan, kegiatan $\mathrm{KKN}$, praktikum dan mengaktifkan institusi/organisasi kemahasiswaan seperti Senat Mahasiswa, Unit Kegiatan Mahasiswa dan Senat Mahasiswa Fakultas.

\section{til. Koordinasi dan Jaringan Penelitian}

Pelaksanaan koordinasi kegiatan penelitian di lingkungan IAIN Raden Intan dewasa ini dilakukan oleh Pusat Penelitian. Tugas ini sejalan dengan Keputusan Menteri Agama Nomor 397 dan 411 Tahun 1993 yang menyatakan bahwa Pusat Penelitian mempunyai tugas melaksanakan, mengkoordinasikan, memantau dan menilai kegiatan penelitian 
KOORDINASI DAN JARINGAN PENELITIAN

Studi pada IAIN Raden Intan Bandar Lampung dalam bidang ilmu pengetahuan agama Islam. Menurut Kepala Balai Penelitian dan Pengabdian pada Masyarat (1996:6) koodinasi yang dilakukan di lingkungan IAIN Raden Intan adalah merupakan proses penyatuan arah pendayagunaan sumber daya (sarana, prasarana, dana) dan upaya yang lengkap dengan seperangkat kegiatan. Hal ini dimaksudkan untuk meningkatkan keterpaduan antara fakultas dan unit-unit kerja terkait di lingkungan IAIN Raden Intan dalam melaksanakan penelitian, pelatihan maupun pertukaran informasi melalui penerbitan jumal penelitian.

Pusat penelitan ini sebenarnya telah terbentuk sejak tahun 1973 dengan nama Lembaga Riset dan Survey yang kemudian berdasarkan Keputusan Menteri Agama Nomor 26 Tahun 1988 berubah nama menjadi Balai Penelitian dan Pengabdian pada Masyarakat. Namun dalam kenyataan hingga saat ini aktivitas Pusat Penelitian masih tampak "mandul", sebagaimana tercermin dalam pelaksanaan yang masih belum optimal. Di antara penyebabnya adalah karena IAIN Raden Intan sampai saat ini belum memiliki secara khusus tenaga fungsional peneliti, sementara semangat meneliti di kalangan tenaga edukatif tampak masih lemah. Dan umunya penelitian yang dilaksanakan oleh para dosen lebih mengacu kepada upaya pengajuan kenaikan pangkat. Demikian pula masih belum memadainya sarana, prasarana dan merupakan kendala yang mendapatkan perhatian yang lebih serius.

Perhatian yang lebih serius terhadap pengelolaan kegiatan penelitan di IAIN Raden Intan mulai dirintis pada tahun 1994. Sejak tahun itu setiap perencanaan maupun pelaksanaan penelitian, dari manapun dana diperoleh, harus dikoordinasikan oleh Pusat Penelitian. Sayangnya dana pendukung kegiatan penelitian masih sangat terbatas baik yang bersumber dari Proyek Perguruan Tinggi Agama Islam (DIP) maupun dari Sumbangan Pembinaan Pendidikan Dana Penunjang Pendidikan (SPPDPP). Selain itu kecilnya dana dari SPPDPP dibanding dengan dana Proyek telah menyebabkan rendahnya minat para dosen untuk meneliti karena terdapat kesenjangan yang cukup lebar. Di masa depan dana penelitian dari SPPDPP yang masih terbilang kecil ini perlu dipertimbangkan.

Karena itu tidak bisa dipungkiri apabila sebagian kegiatan penelitian yang pernah dilakukan tidak dapat dijumpai lagi. Dari penelusuran di lapangan kegiatan penelitian yang sempat ditemui hanya tahun akademik 1991/1992 sampai dengan 1994/1995. Selama 4 tahun tercatat 43 judul penelitian yang dilakukan oleh dosen IAIN dengan perincian : Tahun 1991-1992 sebanyak 11 judul; 1992-1993 sebanyak 4 jadul; 1993-1994 sebanyak 5 judul dan 1994-1995 sebanyak 23 judul (5 di antaranya dibiayai oleh Proyek selebihnya 18 judul oleh SPPDPP). Jika dibanding dengan jumlah dosen sebanyak 132 orang pada tahun akademik 1994/1995 jumlah penelitian dalam tahun yang sama terlihat masih belum berimbang.

Pada umunya kegiatan penelitian lebih banyak dilakukan secara individual dibanding yang kolektif. Begitu juga penelitian yang dilakukan itu cenderung lebih banyak bersifat terapan dari pada penelitian murni dengan aspek kajian yang menonjol berkisar pada pendidikan agama dan keagamaan serta bimbingan/pelayanan hidup beragama. Aspek-aspek lainnya yang tidak terlalu menonjol adalah masalah perkawinan, keluarga, generasi muda, lektur agama, lingkungan hidup, pengembangan pemikiran keagamaan dan tokoh. Bahka'n dari 
KOORDINASI DAN JARINGAN PENELITIAN

Studi pada IAIN Raden Intan Bandar Lampung pengalaman selama ini hasil-hasil penelitian para dosen di fakultas-fakultas itu belum mendukung upaya pemgambilan keputusan, kebijakah atau perencanaan pembangunan di bidang agama. Karena memang data dan informasi yang dihasilkan kurang refresentatif atau belum terkait dengan kebijakan pembangunan atau hasil penelitiannya terlambat diinformasikan kepada pimpinan.

Meski demikian hasil-hasil penelitian tadi tetap diupayakan untuk memberi manfaat bagi kepentingan pengembangan ilmu pengetahuan antara lain dengan didistribusikannya ke berbagai fakultas dalam lingkungan IAIN Raden Intan, Perpustakaan Daerah dan IAIN, Balai Penelitian, sejumlah Perguruan Tinggi di Bandar Lampung, IAIN di seluruh Indonesia dan Departemen Agama Pusat. Kegiatan penelitian ini jiiga dilengkapi dengan penerbitan jurnal penelitian Menara Intan dan berbagai terbitan majalah yang terdapat pada tiap-tiap fakultas.

Kondisi yang dimiliki IAIN Raden Intan tersebut sedikit banyak telah pula mempengaruhi kebijaksanaan dalam penelitian. Misalnya, pada tahun pertama Pelita VI kebijaksanaan yang ditempuh adalah meningkatkan mutu tenaga dosen dengan mengikutsertakan pada berbagai penataran, seminar serta memberikan motivasi agar setiap dosen menambah wawasan pengetahuan mereka melalui penulisan karya ilmiah/penelitian dan mengikuti pendidikan $\mathrm{S} 2$ dan $\mathrm{S} 3$. Sedangkan dalam menjabarkan program pengembangan dan pembinaan penelitian dilakukan kegiatan-kegiatan sebagai berikut:

1. Peningkatan dalam penelitian individu dan kotektif.

2. Partisipasi penelitian dalam rangka mensukseskan pembangunan Nasional melalui Inpres Desa Tertinggal.
3. Upaya penelitian terhadap hasil/dampak KKN IAIN Raden Intan bagi pembangunan Daerah Lampung.

Di pihak lain dalam rangka penyusunan program penelitian yang berkaitan dengan Punas Ristek di lingkungan Departemen Agama perlu dirumtiskafi pengaturan yang terpadu. Melalui pengaturan tersebut diharapkan ketepatgunaan sasaran dan hasil penelitian dalam merumuskan kebijaksanaan dan perencanaan pembangunan di tingkat pusat maupun daerah dapat lebih dicapai. Ini berarti jaringan penelitian antara Badan Litbang Agama dengan lembaga-lembaga penelitian di lingkungan IAIN khususnya menjadi sangat penting dan mendesak. Dalam konteks ini Fauzie Nurdin (1996:17) mengharapkan kepada Badan Litbang Agama agar dapat mengkordinasikan segenap potensi yang dimiliki dan mendayagunakannya secara optimal sarana, prasarana, dana dan sumber daya manusianya.

Untuk dapat menjawab persoalan tersebut Mulyanto Sumardi di dalam makalahnya tentang "jaringan Penelitian Agama di IAIN" menyarakan perlu menciptakan jaringan penelitian intra IAIN (antaf fakultas atau unit dalam lingkungan IAIN sendiri), antar IAIN (antar satu IAIN dengan IAIN lainnya) dan kebijaksanaan yang jelas tentang jenis-jenis penelitian yang dilakukan antara unit-unit kerja dalam IAIN, antara satu IAIN dengan IAIN lainnya, dan antara IAIN dengan Badan Litbang Agama. Jika jaringan penelitian ini terbentuk berarti hubungan kerja IAIN Raden Intan di bidang penelitian akan semakin luas dan komplek. Karena beberapa tahun belakangan ini IAIN Raden Intan telah merintis kerjasama dengan berbagai pihak dalam kapasitas sebagai anggota jaringan penelitian, yaitu 
KOORDINASI DAN JARINGAN PENELITIAN

Studi pada IAIN Raden Intan Bandar Lampung

dengan Badan Perencanaan Pembangunan Daerah (BAPPEDA) Propinsi Daerah Tingkat I Lampung, dengan Universitas Lampung dan dengan jaringan penelitian IAIN se Indonesia.

\section{Penutup}

Pusat Penelitian di lingkungan IAIN Raden Intan telah cukup berfungsi meskipun dalam kondisi yang masih terbatas. Karena kegiatan penelitian yang dilakukan selama ini masih dalam batasbatas untuk memenuhi usul kenaikan pangkat para dosen belum didukung oleh tenaga fungsional peneliti. Dengan lebih dimantapkannya Pusat Penelitian sebagai salah satu fungsi perguruan tinggi tampak adanya kernajuan-kemajuan baik dari segi koordinasi, peningkatan mutu maupun penyebar luasan informasi dan pemanfaatan hasil-hasil penelitian.

Semangat dan minat dosen untuk meneliti perlu terus dipacu sesuai dengan Tri Dharma Perguruan Tinggi. Begitu juga kebutuhan tanaga peneliti pada Pusat Penelitian perlu dicarikan solusi dengan merekrut tenaga-tenaga yunior agar keberadaan Pusat Penelitian menjadi semakin fungsional.

Dalam upaya penyusunan program penelitian yang berwawasan Punas Ristek di Lingkungan IAIN perlu dikembangkan jaringan penelitian dengan Badan Litbang Agama. Hal ini akan sangat bermanfat, terutama dalam memantapkan perencenaan pembangunan di daerah yang sesuai dengan sasaran pembangunan sektor agama pada masa pembangunan Jangka Panjang Kedua dan seterusnya. Namun beberapa hal yang masih perlu dipikirkan adalah penyediaan prasarana, sumber daya peneliti, anggaran/dana serta pedoman kerja.

\section{DAFTAR BACAAN}

IAIN Raden Intan

198820 Tahun Institut Agama Islam Raden Intan Lampung, Lampung.

1992 Laporan Tahunan Institut Agama Islam Negeri Raden Intan Lampung. Panitia Dies Natalis ke-23, Lampung.

1993 Laporan Tahunan Institut Agama Islam Negeri Raden Intan Lampung, Bandar Lampung.

1994 Laporan Tahunan Institut Agama Islam Negeri RAden Intan Lampung, Bandar Lampung.

1995 Laporan Pertangung jawaban Pelaksanaan Tugas Pokok dan fungsi Satuan Organisasi IAIN Raden Intan Bandar Lampung, Tahun 1994/1995, B andar Lampung.

1996 Laporan Rektor Institut Agama Islam Negeri Raden Intan Lampung, Bandar Lampung.

Nurdin, A. Fauzie, Drs., Pengembangan Penelitian Keagamaan di Insititut Agama Islam Negeri Raden Intan Bandar Lampung, Makalah, Bandar Lampung.

Sumardi, Muljanto, Jaringan Penelitian

1996 Agama di IAIN, Makalah, Jakarta. 


\title{
BENDA-BENDA BERSEJARAH BERCIRIKAN ISLAM DI KABUPATEN BONE
}

\author{
H. Abubakar Surur
}

\section{PENDAHULUAN}

\section{Latar Belakang Masalah}

Telah menjadi pengetahuan umum bagi setiap umat beragama, bahwa keidupan beragama berpangkal pada kepercayaan terhadap agama yang diyakininya, yang direfleksikan dalam kehidupan nyata sebagai insan beragama, sekaligus sebagai anggota masyarakat.

Salah satu wujud refleksi keyakinan agama dari masyarakat, adanya bendabenda fisik bercirikan keagamaan yang dimiliki kelompok-kelompok masyarakat. Benda-benda tersebut dapat berwujud bangunan seperti candi, pura, gereja dan masjid; berbentuk patung, nisan kubur, maupun alat upacara kenegaraan/kerajaan atau keagamaan serta alat-alat keperluan lainnya. Tipe, bentuk dan variasi bendabenda tersebut mengekspressikan seni budaya yang diilhami rasa agama dari kelompok masyarakat menurut zamannya.

Keberadaan artefak keagamaan pada suatu kelompok masyarakat, dilatarbelakangi oleh seperangkat nilai dan konsep yang dianut masyarakat setempat menurut kondisi zamannya. Nilai dan konsep itu merupakan perpaduan dari nilai-nilai budaya dan agama yang dianut masyarakat yang memotivasi perlakuan mereka terhadap artefak keagamaan yang bersangkutan.

Dalam perjalanan sejarahnya, artefak keagamaan itu mengalami perobahanperobahan, namun esensinya tetap ada, selama artefak keagamaan itu sendiri masih diperlukan oleh masyarakat pendukungnya.

Obyek penelitian adalah benda- benda bersejarah bercirikan keagamaan (Islam). Menurut Nugroho Susanto (1971 : 2) : Istilah sejarah mempunyai dua arti. Sejarah sebagai peristiwa-peristiwa masa lampau, dan sejarah sebagai kisah daripada peristiwa itu.

Benda-benda bersejarah adalah benda yang erat kaitannya dengan peristiwa masa lampau dan merupakan salah satu sumber sejarah. Benda-benda bersejarah, ada yang berbentuk artefak dan ada pula yang merupakan benda alam.

Artefak ialah benda-benda yang dibuat dengan tangan manusia yang dipergunakan untuk keperluannya (Sumadi, 1982 : 125).

Masalah yang memerlukan jawban sehubungan dengan keberadaan artefak keagamaan yang dianut, adalah:

a. Bagaimana keberadaan artefak keagamaan dilihat dalam dimensi ruang, waktu dan bentuknya.

b. Nilai dan konsep apa yang melatarbelakangi perlakuan masyarakat terhadap artefak keagamaan milik mereka.

c. Bagaimana perlakuan masyarakat terhadap artefak keagamaan milik mereka

\section{Tujuan dan Kegunaan Penelitian}

Penelitian ini bertujuan untuk mengungkap keberadaan artefak keagamaan bercirikan Islam dan menge- tahui perlakuan masyarakat terhadapnya serta nilai dan konsep yang melatarbelakangi perlakuan itu.

Hasil penelitian ini, diharapkan dapat bermanfaat bagi Departemen Agama (Bidang Penerangan Agama Islam) dan 
Depdikbud serta instansi terkait lainnya, sebagai masukan dalam rangka pengambilan kebijaksanaan berkaitan dengan pelestarian budaya bangsa.

Disamping itu, juga bagi masyarakat untuk mengetahui nilai benda-benda bersejarah yang berkaitan dengan budaya bangsa.

\section{Metode Penelitian}

Sasaran penelitian ini adalah bendabenda bersejarah bercirikan Islam di Kabupaten Bone. Pengumpulan data dilakukan dengan tekhik :

a. Wawancara mendalam dengan tokoh adat, tokoh agama, dan sesepuh masyarakat.

b. Observasi ke tempat-tempat bersejarah dan pengamatan benda-benda bersejarah yang masih tersimpan, baik di Museum Lagaligo Kotif Watampone, maupun di tempat lainnya.

c. Studi pustaka

Pengolahan data dilakukan dengan analisis deskriptif.

\section{SELAYANG PANDANG KABUPATEN BONE}

\section{Letak dan Alam}

Kabupaten Bone adalah daerah terbesar dan terbanyak penduduknya diantara 23 kabupaten/kotamadya di Propinsi Sulawesi Selatan, dengan ibukotanya Kotif Watampone. Letak kabupaten Bone berada dipesisir timur Sulawesi Selatan, membujur dari utara ke selatan sepanjang pesisir Teluk Bone, dan berbatas : sebelah utara dengan Kabupaten Wajo, sebelah timur dengan Teluk Bone, sebelah selatan dengan Kabupaten Maros, Barru, Soppeng dan Pangkajene Kepulauan. Jarak Kabupaten Bone (Watampone) dengan Ujungpandang, Ibukota Propinsi Sulawesi Selatan, ditempuh melalui tiga jurusan, yaitu ; ke selatan melalui Sinjai, ke utara melalui Pare-Pare dengan jarak \pm 300 km, dan jurusan barat melalui Maros dengan jarak $174 \mathrm{~km}$. Disamping transportasi darat, Kabupaten Bone juga menjadi penghubung bahkan menjadi urat nadi perekonomian antara Sulawesi Sela tan dengan Sulawesi Tenggara melalui laut dengan Pelabuhan Bajoe-Kolaka.

Kabupatert Bone terdiri dari daerahdaerah pegunungan, terutama di bagian barat, daerah pantai dibagian timur sepanjang pesisir Teluk Bone dan daratan dibagian selatan dan utara.

Luas Kabupaten Bone 455.900 ha $(4559 \mathrm{~km})$ terdiri dari sawah $75.437,93$ ha (17\%), ladang/kebun 108.938 .05 ha (26\%), tanah kering 138.450 ha (22\%), hutan 167.303 ha $(19 \%)$, empang/perikanan $11.945,44$ ha (9 \%), pemukiman/pekarangan 8.960 ha $(5 \%)$, dan lain-lain 7.600 ha $(2 \%)$.

Iklim di Kabupaten Bone termasuk subtropica karena berada di lintang selatan dan dikenal dua musim dalam setahun, yaitu :

a

a. Musim hujan dari bulan Maret sampai bulan Agustus. Pada musim hujan, petani menggarap sawah untuk menanam padi, yang pada umumnya adalahsawah tadah hujan seluas 58.779.83 ha dan hanya 16.268 .1 ha yang menggunakan pengairan. Musim ini dikenal masyarakat Bone dengan "bare" (musim barat).

b. Musim kemarau dari bulan Desember sampai Pebruari. Pada musim kemarau, petani yang berada di daerah pegunungan menanam jagung dan palawija, dan petani yang berada di 


\section{BENDA-BENDA BERSEJARAH BERCIRIKAN ISLAM}

\section{KABUPATEN BONE}

pesisir pantai berlayar ke daerah lain mencari nafkah tambahan. Musim kemarau disebut juga "timo" (musim timur).

\section{Penduduk}

Menurut sensusnas 1993, penduduk Kabupaten Bone berjumlah 613.916 jiwa, terdiri dari laki-laki 284.093 orang $(46,28 \%)$ dan wanita 329.823 orang $(53,72 \%)$. Dibandingkan luas wilayah dengan jumlah penduduk, maka kepadatan penduduk rata-rata 135 orang $/ \mathrm{km}$. Jumlah penduduk tersebut tersebar pada 25 kecamatan.

Keadaan penduduk menurut usia, di bawah usia 10 tahun 230.574 orang dan usia 10 tahun ke atas 383.342 orang. Distibusi penduduk yang berusia 10 tahun ke atas menurut pendidikan yang ditamatkan, tahun 1993/1994, adalah : Tidak tamat SD 145.454 orang $(37,94 \%)$, tamat SD 150.681 orang $(39.31 \%)$, tamat SMTP 40.177 orang $(10.48 \%)$, tamat SMTA 38,902 orang $(10,15 \%)$ dan alumni Perguruan Tinggi/Akademi 7.858 orang $(2,12 \%)$.

Menurut sensusnas 1993, penduduk usia 10 tahun ke atas yang bekerja sesuai pekerjah utama, berjumlah 245.318 orang, terdiri atas : Petani 159.719 orang (65.10\%), Buruh pertambangan 1.068 orang $(0,44 \%)$, Buruh bangunan 2.961 orang $(1,21 \%)$, Industri/Ketrampilan 16.554 orang $(6,75 \%)$, Pedagang/Pengusaha 26.514 orang $(10,01 \%)$, Pengangkutan/Komunikasi 6.660 orang $(2,71 \%)$, Pegawaia Negeri/ABRI/Pensiunan 30.961 orang $(12,62 \%)$, jasa dan lain-lain 890 orang $(0,36 \%)$. Dari penduduk yang memiliki lapangan kerja utama, yang paling banyak adalah petani, terdapat $65,10 \%$. Hal ini berkaitan dengan luasnya daerah pertanian di Kabupaten Bone. Karena itu Kabupaten Bone termasuksalah satu lumbung padi (lappoase) di Sulawesi Selatan.

\section{Sejarah Singkat Kabupaten Bone}

Sumber lontarak menyebutkan, bahwa sebelum kerajaan terbentuk, manusia di Bone hidup berkelompok-kelompok yang disebut "anang" (kaum) dipimpin seorang "matowa" (ketua). Masing-masing kelompok diikat oleh hubungan keturunan dari Sawerigading, namun lama kelamaan turunan Sawerigading kabur, akhirnya terjadi kekacauan dan permusuhan antar kelompok, karena cara hidup dan adat istiadat yang dipegang pada waktu itu tidak diabaikan lagi. Akibatnya timbul istilah "sianre bale tauwe" (yang kuat berkuasa yang lemah jadi mangsa). Keadaan seperti ini berlangsung sampai "pitupariama" (tujuh generasi). Dalam keadaan kacau demikian, muncul seorang tokoh, mereka sebut "To Manurung" (orang yang turun dari ketinggian), berusaha mempersatukan kembali dan mengkhiri permusuhan antar kelompok.

Melalui persepakatan para matowa, mereka mendatangi To Manurung dengan maksud agar To Manurung bersedia diangkat menjadi raja. Maksud mereka dinyatakan antara lain : "Iyyanamai kilaowang riko, maelokkeng tamaseang, tamaraddenna mai ri tana Bone aja'na tallajang, tudangni mai naidinna kipo-puang

(Kami datang kepadamu, kami harap kau mengasihani kami, tinggallah di Bumi Bone, jangan lagi pergi. Duduklah memerintah dan kami jadikan engkau raja......). To Manurung menjawab: "Ujujungngi uparibotto kulu, upate ri pakka-pakka ulaweng ada-adamu to maegae, riwettu mabbulo sipeppamu maelo pancajika arung" (Aku junjung di atas kepala, aku tempatkan kata-katamu hai orang banyak, ketika kamu sekalian bersatu padu menerima aku sebagai raja). 


\section{BENDA-BENDA BERSEJARAH BERCIRIKAN ISLAM DI KABUPATEN BONE}

To Manurung diangkat menjadi Raja Bone yang pertama, bergelar "To Manurung ri Matajang Mattasi Lompoe", pada tahun 1326. Luas kerajaan Bone waktu itu sekitar $6 \mathrm{~km}$ berpusat di Lalengbata (Watampone).

Kerajaan Bone dibawah To Manurung, semakin hari semakin hari semakin berkembang dan kerajaan kecil yang ada di sekitarnya berangsur-angsur menggabungkan diri seperti Kerajaan Awangpone, Pattiro, Cina, Palakka dan lain-lain.

Dalam pelaksanaan pemerintahan ${ }^{\wedge}$ To Manurung membentuk "Ade Pitu", ditunjuk dari raja-raja disekitar Kerajaan Bone, dan menetapkan aturan-aturan (ade) untuk dipedomani, yaitu : Pertama, menentukan hak milik rakyat, yang sebelumnya tidak ada aturan mengenai hak milik rakyat sehingga menimbulkan kesewenangan. Kedua, menertibkan keadaan masyarakat. Ketiga membuat "bate" (bendera) yangt dinamakan "worongporonge" (kesatuan kelompok) yang selalu dibawah bila raja bepergian. Keempat, Rakyat Bone disatukan dalam ikatan yang bernama "Kawerang Tana Bone" (Ikatan Persekutuan Bone) yang bekerja dan bergotong royong untuk memakmurkan kerajaan Bone.

Beberapa waktu setelah menjadi raja, To Manurung kawin dengan "Manurunge ri Tiro". Dari perkawinan ini lahir La Ummasa, Pattanra Wanuae, Tenri Salogo, We Arattiga dan I Samateppa.

To Manurung menjadi Raja Bone (Arumpone) selama 32 tahun (1326-1358), kemudian digantikan oleh putera sulungnya, La Ummasa, yang memerintah selama 66 tahun (1358-1424). Keadaan pemerintahan selama La Ummasa menjadi Arumpone kedua, digambarkan dalam La Toa, antara lain :.... mappettu tauwe ri assisalangnge, parelleseng riallappori ase....... (rakyat berhenti dari pertikaian dan balik rumah penuh padi) artinya : persatuan terpelihara dan kemamuran dirasakan rakyat.

Bone dalam bentuk kerajaan, mulai tahun 1326 sampai tahun 1960 (634 tahun) terlah diperintah sebanyak 32 raja bergelar Mangkau ri Bone, dintaranya 5 orang wanita. Raja terakhir adalah La Mappanyukki Sultan Ibrahim Arumpone Matinroe ri Gowa, Raja ini dua kali menduduki tahta, masing-masing tahun 18311946 dan tahun 1957-160.

\section{Sekilas Masuknya Islam}

Islam masuk ke Bone oada tahun 1611, ketika La Tenriruwa Sultan Adam Matinroe ri Bantaeng menjadi Arumpone ke 11, atas ajakan Raja Gowa Sultan Alauddin Daeng Manrabia, yang diterima baik oleh La Tenriruwa, namun, rakyat bersama Ade Pitu belum mau menerimanya. Akibatnya La Tenriruwa meniggalkan Kerajaan Bone dan sebagao penggantinya dilantik La Tenripale To Akkap-peang menjadi Arumpone ke 12. Mulanya La Tenripale tidak setuju masuknya Islam di Bone, sehingga ia memimpin rakyat Bone melawan Raja Gowa, yang berpangkalan di Pallette. Akhirnya La Tenripale bersama rakyatnya kalah dalam perang dan takluk pada Raja Gowa, sehingga masuk Islam. Setelah memeluk Islam, La Tenripale sering ke GOwa untuk mempelajari Islam dari Khatib Tunggal Datuk Ri Bandang, sampai akhirnya beliau wafat di Tallo dan digelar La Renripale To Akkappeang Sultan Abdullah Arumpone Matinroe ri Tallo.

Dalam pemerintahan Latenripale Sultan Abdullah, Islam berkembang di Kerajaan Bone dan seluruh rakyat Bone menerima Islam sebagai agama satu-satunya, sedang agama lain tidak diberi kesempatan berkembang. Kepercayaan animisme yanbg dulunya dipertahankan, tidak mendapat tempat lagi dihati rakyat Bone. Bahkan syariat Islam dimasukkan 


\section{BENDA-BENDA BERSEJARAH BERCIRIKAN ISLAM DI KABUPATEN BONE}

salahsatu unsur pangadereng, yang mulanya hanya empat, yaitu ade, rapang, wari, bicara, lalu ditambah dengan sara' menjadi unsur kelima.

\section{BENDA-BENDA BERSEJARAH BER- CIRIKAN ISLAM DI KABUPATEN BONE}

Dalam penelitian ini, yang diamati adalah benda-benda bersejarah bercirikan agama Islam, dan dibatasi dalam dimensi tempat (Kabupaten Bone), waktu dan bentuk tertentu. Dalam dimensi waktu dibatasi mulai awal islamisasi di Kabupaten Bone sesuai keberadaan artefak keagamaan yang diamati, dan bentuk dibatasi pada masjid, makam dan alat-alat kerajaan yang ada di Kabupaten Bone.

\section{Masjid}

Masjid al-mujahidin, lebih dikenal dengan "Masjid Tua" terletak di Kelurahan Bukaka, Kecamatan Tanete Riattang letaknya di Suatu ketinggian dan di depan mihrab terdapat makam raja dan keluarganya dan di samping kanan masjid adalah kuburan untuk masyarakat umum.

Masjid tua ini didirikan pada tanggal 15 September 1752 oleh Raja Bone kedua belas yang bernama La Temmassonge Sultan Abdul Razak Jalaluddin, Matinroe ri Malimongang. Pada mulanya masjid tua dibangun terbuat dari kayu tetapi telah tiga kali mengalami renovasi tanpa merubah besar dan bentuknya, masing-masing :

Pertama, pada tahun 1775 oleh Raja Bone ke-14, Toappatunru Sultan Ismail Muhammad Tajuddin, Matinroe ri Lalengbata, yang dikuburkan di depan mihrab masjid tua.

Kedua, pada tahun 1890 oleh Raja Bone ke-31. La Pawaoi Karaeng Segeri Matinroe ri Bandung.

Ketiga, pada tahun 1922, dipelopori oleh Qadhi Bone (Petta KaliE) yang dipangku oleh H. Abdul Hamid.
Masjid tua direnovasi dengan bangunan beton tetapi bentuk aslinya tetap dipertahankan, berukuran $19 \times 21$ meter, tiang utama 4 buah dengan garis tengah 1 meter, tiang pendukung 12 buah dengan garis tengah setengah meter. Mihrab dari beton sebesar $2 \times 3$ meter, mimbar 1 × 3 meter, pintu papan 9 buah dan jendela 2 buah terdapat di bagian depan. Atap berbentuk tungkung, dipuncaknya dihiasi dengan "balubu" keramik asli sejak awal didirikannya, begitu juga di atas mihrab dan di puncak mimbar, dipasang balubu yang utuh sampai sekarang. Di kiri kanan dan bagian timur masjid, dibuat selasar dengan dinding tembok setinggi 1,40 meter dan tebalnya setengah meter, yang dapat diduduki jamaah saat menunggu waktu shalat.

Padatahun 1981 dibangun sebuah menara agak terpisah dari masjid. Pada dasar menara dibangun tempat berwudhu sekeliling menara. Pembangunannya atas bantuan H. Andi Oddang, Gubernur Propinsi Sulawesi Selatan, waktu itu.

Masjid Tua "Al-Mujahidin" dewasa ini tidak digunakan lagi untuk shalat Jum'at (karena sudah dibangun Masjid Raya, tidak jauh dari Masjid Tua), tetapi shalat jamaah tetap ramai setiap lima waktu. Pembinaan keagamaan dilaksanakan di masjid ini secara rutin dengan sistem pengajian (halqoh) tiap selesai shalat magrib dan subuh, oleh para ulama yang ada di Watampone secara bergantian.

Di lingkungan masjid, sebelah barat, dibangun Madrasah Diniyah, tetapi kegiatan dan pembinaan santri dipusatkan di Masjid Tua Al-Mujahidin. 


\section{BENDA-BENDA BERSEJARAH BERCIRKAN ISLAM DI KABUPATEN BONE}

2. Makam

Makam yang terjaring dalam penelitian ini, pada umumnya mempunyai nilai pelestarian budaya yang melatarbelakangi keberadaannya, disamping menjadi tempat ziarah bagi mereka yang merasa masih mempunyai garis keturunan dengan raja yang bersangkutan, maupun masyarakat lainnya.

a. Makam Raja Bone XIII

Makam Raja Bone ke-13, La Maddaremmeng Sultan Malikul Saleh Matinroe ri Bukaka, meninggal tahun 1640. Terletak di Komplek Pemakaman Bukaka. Makam tersebut dipisahkan dari makam lainnya. Sebuah kubah dibangun dari batu merah dan diplaster semen setebal $0,80 \mathrm{~cm}$ seluas $3,5 \mathrm{x}$ $3,5 \mathrm{~m}$.

Jirat makam terbuat dari kayu hitam, panjangnya $2,70 \mathrm{~m}$ dan lebar $0,75 \mathrm{~m}$. Jirat berundak tiga dihiasi dengan relif berpola kembang. Nisan juga dibuat dari kayu hitam sebanyak dua buah, tinggi nisan dibagian kepala $0,78 \mathrm{~m}$ dan dibagian kaki 0,65 $\mathrm{m}$. Kedua nisan, selain terdapat relif motif bunga, juga terdapat inskripsi kaligrafi dalam bundaran, tertulis :

Dahulu makam ini banyak dikunjungi masyarakat dengan maksud tertentu, tetapi dewasa ini sudah jarang karena pihak berwenang berusaha mencegah perlakuan yang mengarah kepada syirik. Usaha tersebut antara lain, makam dibuatkan pagar dan pintunya dikunci, tetapi tetap dibuka bila ada pengunjung untuk ziarah.

b. Makam Raja Bone XIV

Makam Raja Bone ke-14, Toappa- tunru Sultan Ismail Muhammad Tajuddin Matinroe ri Lalengbata, meninggal tahun 1823. Makam ini terletak di depan mihrab masjid tua Al-Mujahidin. Makam tersebut pada mulanya, tidak seperti keadaannya sekarang, karena telah diperbaiki. Aslinya, yang terlihat sekarang tingal nisannya. Pada tahun 1930, makam ini diupgrade oleh "Ade Pitu". Jiratnya mengalami perubahan dengan bentuk berundak dua dan temboknya dibungkus dengan keramjk berwarna putih. Panjangnya $2 \mathrm{~m}$, lebar $0,93 \mathrm{~m}$ dan tinggi $0,60 \mathrm{~m}$. Bagian atas jiratnya terbuka, ditaburi dengan kerikil. Nisan dua buah, bentuk dan besar keduanya sama, terbuat dari beton.

c. Makam Raja Bone XVI Makam Raja Bone ke-16, La Patau Matanna Tikka Sultan Alimuddin Idris, Matinroe ri Nagauleng, terletak di Komplek Pemakaman keluarga raja di Desa Nagauleng, Kecamatan Cenrana, bagian utara Kabupaten Bone.

Walaupun kompleks pemakaman ini telah ditumbuhi semak-semak, namun makam raja masih dapat ditandai, karena dibuat lebih tinggi dari makam lainnya. Temboknya ditumbuhi rumput dan berlumut, sehingga relifnya tidak dapat lagi terbaca. Nisannya diia buah juga sudah berlumut.

Pemakaman ini nampaknya tidak terurus dan tidak pernah didatangi pengunjung, bahkan hampir tertutup dengan pohon-pohon besar dan kecil. Pemakaman ini tidak digunakan untuk umum, hanya untuk keluarga raja.

d. Makam Raja Bone XXIX

Makam Raja Bone ke-29, Singke- 


\section{BENDA-BENDA BERSEJARAH BERCIRIKAN ISLAM \\ DI KABUPATEN BONE}

\begin{abstract}
rurukka Sultan Ahmad Idris Matinroe ri Topaccing, situsny a berdekatan dengan benteng Bajoe. Makam ini sangat sederhana, dan nampaknya kurang layak disebut sebagai makam raja. Dasar makam rata dengan tanah disekelilingnya, hanya kijangakam masih dapat diketahui batasnya dengan adanya tonggak-tonggak batu berpahat yang dipancangkan berkeliling berbentuk segi empat panjang, berukuran $1.50 \mathrm{~m} \mathrm{x}$ $1.50 \mathrm{~m}$. Nisan dua buah terbuat dari batu bersegi empat tanpa bentuk, besarnya $0.15 \mathrm{~m} \times 0.15 \mathrm{~m}$ dan tingginya $0.60 \mathrm{~m}$, dipancangkan tidak tegak tetapi agak miring ke luar.
\end{abstract}

Arumpone ke-29, Singkerurukka, dikenal penganut dan penyebar Tarekat Khalwatiyah Samman, maka kuburannya banyak dikunjungi jamaah tarekat khalwatiyah, bukan hanya dari sekitar Desa Bajoe, tetapi dari luar datang berkunjung terutama di hari Jum'at.

\section{Alat-alat Kerajaan}

Alat-alat kerajaan yang menjadi sasaran penelitian adalah alat-alat kerajaan yang bercirikan Islam atau dibuat dengan motif Islam. Dari sekian banyak alat-alat kerajaan yang tersimpan di Museum La Pawawoi Kotif Watampone, hanya 2 macam yang ditemukan, yaitu Bendera dan Stempel Kerajaan.

\section{a. Bendera}

Bendera yang masih tersimpan di Museum La Pawawoi, sebagai tempat yang banyak menyimpan benda-benda bersejarah, bermacam-macam, antara lain bendera yang bernama : Sampara- jae, Garudae, Cellae dan Manue,namun bendeera-bendera tersebut tidak didapati ciri Islam. Bendera yang dapat digolongkan benda bersejarah bercirikan Islam, yang masih tersimpan di Museum La Pawawoi adalah bendera kerajaan terbuat dari kain sutera berwarna biru laut, berukuran 3 x $2 \mathrm{~m}$. Pola hias yang dinilai bercirikan Islam, adanya bintang 7 buah di stidut kanan atas sebanyak tiga baris, bersusun dari bawah ke atas. Di bawah empat bintang, di tengah dua bintang dan di atas satu bintang, sehinggabintang-bintang tersebut tersusun seperti sebuah kerucut.

Bendera ini sudah cukup tua sehingga susah dibuka dari Hpatannya. Bentuk dan ukurannya diperoleh informasi dari Andi Mappasissi, pemimpin museum tersebut.

Kalau bendera lainnya dibawa sebagai simbol kekuatan bila terjadi peperangan, tetapi bendera yang satu ini hanya dikibarkan di istana raja (Soraja) sebagai bendera kerajaan.

Penyimpanan bendera sebagai alat kerajaan di Kabupaten Bone, mempunyai nilai pelestarian budaya dan bukti sejarah masa lampau.

\section{b. Stempel}

Selain bendera kerajaan, di Museum La Pawawoi Kotif Watampone tersimpan juga stempel yang pernah dipakai Raja Bone dizamannya, stempel tersebut umumnya dibuat dari besi dengan bentuk yang bermacam-macam. Penyimpanan stempel sebagai alat kerajaan adalah pemeliharaan warisan dari leluhur, yang bernilai budaya. 


\section{BENDA-BENDA BERSEJARAH BERCIRIKAN ISLAM}

DI KABUPATEN BONE

Sebuah stempel yang bagian mukanya bermotif kembang bermahkota delapan. Dalam lingkup suatu garis bundaran tertera tulisan, yang isinya doa' untuk Sultan Saleh Muhyidin. Bila diperhatikan nama yang tertera dalam stempel tersebut, digunakan oleh Raja Bone ke-29, La Parenrengi Sultan Saleh Muhyiddin Matinroe ri Ujung Benteng Selayar.

Stempel lain yang hampir sama bentuknya dengan stempel yang disebutkan di atas, bedanya hanya daun mahkota berbentuk setengah bundaran. Tulisan yang terdapat pada stempel ini berbunyi :

Nama Raja yang tertulis adalah Sultan Saleh Syamsuddin yang diduga nama lain dari Sultan Saleh Muhyiddin.

Sebuah stempel yang juga tersimpan di Museum La Pawawoi, stempel yang berbentuk segi delapan sama sisi bertuliskan sebagai berikut :

Melihat nama dalam stempel tersebut, maka stempel itu adalah digunakan Raja Bone ke-24, La Temmassonge Sultan Abdul Razak Jalaluddin matinroe ri Malimongang, stempel tersebut digunakan pada tahun $1275 \mathrm{H}$.

Stempel lain yang tersimpan, stempel yang berbentuk segitiga sama sisi, terdapat tulisan berbunyi :

Nama yang tercantum dalam stempel tidak terdapat dalam susunan raja-raja Bone dan tidak diketahui siapa yang mempunyai gelar tersebut.

Sebuah stempel yang ditemukan, berbentuk segi empat dan sisi bagian atasnya melengkung. Dalam stempel ini terdapat tulisan :
Stempel ini diduga keras milik Raja Bone ke-29, Singkerurukka Sultan Ahmad Idris Matinroe ri Topaccing.

Ada sebuah stempel ditemukan juga, tidak terdapat nama seseorang seperti stempel lainnya, bentuknya bundar bertuliskan :

Dari tulisan itu diduga bahwa stempel itu dipergunakan oleh kalangan keluarga raja, tetapi tidak diketahui lagi siapa yang membuatnya, dan tidak jelas raja yang menggunakannya.

\section{PENUTUP}

Kabupaten Bone sebagai bekas kerajaan, masih tersimpan peninggalan bendabenda budaya yang bernilai sejarah, khususnya benda-benda bersejarah bercirikan Islam. Agama Islam cukup lama berkembang, mulai tahun 1611 sampai sekarang, sehingga pengaruh ajaran Islam telah mewarnai prilaku dan cara hidup raja dan rakyat Bone, ternyata simbol-simbol yang digunakan oleh raja-raja pada alat-alat kerajaan, bahkan makam raja, hampir semuanya bercorak Islam.

Benda-benda bersejarah bercirikan Islam sebagai hasil temuan penelitian, sebagian masih utuh dan terpelihara seperti masjid dan stempel kerajaan, sebagian juga sudah memprihatinkan karena termakan usia, seperti bendera dan makam.

Keberadaan benda-benda budaya tersebut merupakan bagian dari budaya nasional yang mempunyai nilai dan bukti sejarah masa lampau, yang harus dilestarikan.

Pemugaran benda-benda budaya, sebagaimana telah dilakukan pemerintah, 


\section{BENDA-BENDA BERSEJARAH BERCIRIKAN ISLAM}

DI KABUPATEN BONE

perlu didukung oleh seroua lapisan masyarakat, terutama benda-benda yang mengalami kerusakan berat seperti makam, demi untuk menyelematkan benda-benda tersebut dari kepunahan.

\section{KEPUSTAKAAN}

Abdullah, Taufik^gama dan Perubahan Sosial, CV. Rajawali, Jakarta, 1983.

Ali, Andi Muh.Bone Selayang Pandang, Kantor Departernen P dan K Kabupaten Bone, Watampone, 1969.

Gazalba, SidiMesjid Pusat lbadah dan Kebudayaan Islam, Pustaka Antara, Jakarta, 1983.

Hadimulyo, Drs., dkk. Sejarah Kuno Sulawesi Selatan, Kantor Suaka Peninggalan Sejarah dan Purbakala Wilayah Sulawesi Selatan, Ujungpandang, 1979.

Notosusanto, Nugroho Norma-norma Dasar Penetitian dan Penulisan Sejarah, Departernen Hankam Pusjarah ABRI, Jakarta, 1971.
Sessu, Drs. Amir Relung-Relung Sejarah Tana Bone, Jilid I, Kantor Depdikbud kabupaten Bone, Watampone, 1986.

Benda-Benda Bersejarah Bercirikan Keagamaan di Sulawesi Selatan, Balai Penelitian Lektur Keagamaan, Ujungpandang, 1984/1985. 